\title{
Kontribusi Partai Politik di Tengah Pandemi Covid-19 di Kabupaten Gowa
}

\author{
Ramlah \\ Jurusan Sosiologi Agama UIN Alauddin Makassar \\ e-mail: ramlahrara9898@gmail.com
}

\begin{abstract}
Abstrak
Tulisan ini mencoba mencari fakta dan pendapat masyarakat tentang peran partai politik di Kecamatan Tompobulu Kabupaten Gowa di tengah pandemi Covid-19. Secara garis besar, tulisan ini bertujuan untuk memahami dan mengetahui peran partai politik dalam membantu penanganan Covid-19 dan untuk mengetahui bagaimana pandangan masyarakat tentang peran partai dalam membantu penanggulangan Covid-19. Penelitian ini menggunakan metode penelitian kualitatif deskriptif untuk menggambarkan sejauhmana partai politik berkontribusi dalam penanganan pandemi Covid-19 di Tompobulu. Kesimpulan tulisan ini adalah bahwa beberapa partai politik berkontribusi dengan cara membagi Alat Pelindung Diri (APD) ke Puskesma Tompobulu, namun demikian masyarakat menginginkan kontribusi yang lebih.
\end{abstract}

\section{Kata Kunci:}

Partai Politik, Covid-19, Tompobulu, Gowa

\section{PENDAHULUAN}

Partai politik merupakan elemen penting dalam negara demokrasi. Salah satu fungsi dibentuknya partai politik adalah sebagai institusi politik yang bertanggung jawab dalam memberikan pendidikan politik kepada kader maupun kepada masyarakat luas. Dalam sistem politik yang demokratis, partai politik menjadi pilihan masyarakat sebagai alat untuk mewujudkan cita-cita bangsa dan negara. ${ }^{1}$

\footnotetext{
${ }^{1}$ Payerli Pasaribu, "Peranan Partai Politik dalam Melaksanakan Pendidikan Politik, JPPUMA: Jurnal Ilmu Pemerintahan dan Sosial Politik, 5 (1) (2017): 51-59.
}

Partai politik seharusnya melaksanakan peran dan fungsinya dengan baik sehingga dapat menjadikan suatu negara yang demokratis, tetapi pada kenyataannya tidak semua fungsi tersebut telah dilaksanakan oleh partai-partai politik yang ada. Mengingat fungsi partai politik yang begitu penting, bahkan keberadaan dan kinerjanya merupakan ukuran mutlak bagaimana demokrasi berkembang disuatu negara. Meskipun ia bukan merupakan pelaksana pemerintahan, namun keberadaannya akan mempengaruhi bagaimana 
dan arah mana pelaksanaan pemerintahan dijalankan. ${ }^{2}$

Peranan partai politik tidak hanya dalam proses politik, namun peranan mereka saat terjadi bencana alam atau masalahmasalah yang terjadi di masyarakat seperti yang melanda dunia, pandemi Covid-19, kontribusi mereka juga dibutuhkan. Melalui anggota-anggotanya yang duduk di lembaga legislatif maupun eksekutif mewakili rakyat untuk memperjuangkan kepentingan rakyat bersama. Pada sisi lain, partai politik seharusnya menjadi saluran partisipasi politik bagi warga negara untuk ikut serta mempengaruhi pengambilan keputusan oleh pemerintah.

Selama ini, calon anggota legislatif jelang pemilihan intens memberikan bantuan dengan simbol-simbol partainya, bantuan sembako bahkan sampai pada baju kaos, syal, jilbab, mukena, uang dan masih banyak lagi bantuan lainnya. Namun di saat pandemi ternyata aksi simbol partai menurut observasi awal dari media online masih minim, bisa kita hanya partai politik tertentu yang turut memberikan bantuan dan support terhadap penanganan pandemi ini. Walaupun skalanya pusat, sementara provinsi dan daerah belum menyentuh ke daerah-daerah pelosok seperti fenomena menjelang pemilu partai politik.

Dalam situasi seperti ini, makna hadirnya bantuan tentu menjadi penting, baik berupa bantuan yang bersifat masif maupun bantuan sederhana. Namun

\footnotetext{
${ }^{2}$ Payerli Pasaribu, 2017, h. 23.
}

beberapa partai politik seperti yang terlihat di Kecamatan Tompobulu, Kabupaten Gowa, berupaya mengambil momentum ini untuk memberikan bantuan sederhana kepada masyarakat demi menarik simpati serta sebagai upaya menjawab kesan bahwa partai politik hanya hadir di saat pemilihan saja. ${ }^{3}$

Berdasarkan latar belakang di atas, tulisan ini bertujuan untuk mengetahui peran partai politik dalam membantu penanganan Covid-19 di Kecamatan Tompobulu, Kabupaten Gowa. Serta untuk mengetahui bagaimana pandangan masyarakat tentang peran partai dalam membantu penanganan Covid-19.

\section{METODE PENELITIAN}

Dalam penulisan karya ilmiah tidak bisa lepas dari metode penelitian yang menjadi pedoman dalam proses pengambilan data dilapangan sampai pada proses analisis data. Adapun jenis penelitian yang digunakan adalah metode penelitian kualitatif. Adapun teknik pengumpulan data dilakukan dengan observasi dan wawancara. Wawancara dilakukan terhadap masyarakat Kecamatan Tompobulu Kabupaten Gowa.

\section{PEMBAHASAN}

Severe Acute Respiratory Syndrome Coronavirus 2 (SARS-CoV-2) pertama

\footnotetext{
${ }^{3}$ PinterPolitik.Com, "PKS-Demokrat Bersinar Di Tengah Corona" dalam https://www.pinter politik.com/pks-demokrat-bersinar-di-tengahcorona/, diakses 20 Mei 2020.
} 
kali ditemukan di kota Wuhan, Cina, pada akhir Desember 2019. Virus ini menular dengan cepat dan telah menyebar ke wilayah lain di Cina dan ke beberapa negara, termasuk Indonesia. Hal ini membuat beberapa negara menerapkan kebijakan untuk memberlakukan lockdown dalam rangka mencegah penyebaran virus Corona.

Coronavirus Disease 2019 (Covid-19) sedang menjadi momok menakutkan di berbagai belahan dunia tidak terkecuali di Indonesia. Di Indonesia sendiri tercatat per 20 Mei 2020 yakni total kasus 19.189, bertambah 693 pada hari sebelumnya. Adapun pasien yang meninggal sebanyak 1,242 orang sedangkan pasien yang sembuh berjumlah 4,575 pasien. $^{4}$

Sedangkan update Covid-19 Sulawesi Selatan pada tanggal yang sama yakni total 1064 orang, bertambah 47 kasus dari hari sebelumnya. Adapun pasien yang meninggal sebanyak 132 orang sedangkan pasien yang sembuh berjumlah 358 pasien. $^{5}$

Data di atas menunjukkan bahwa pertambahan kasus positif Covid-19 sangat mengkhawatirkan. Di susul dengan kebijakan pemerintah yang memberlakukan pembatasan aktivitas masyarakat, menjadi beban tersendiri. Dengan adanya pembatasan tersebut, maka secara tidak

\footnotetext{
${ }^{4}$ Gugus Tugas Percepatan Penangan Covid19, "Data Sebaran" dalam covid19.co.id, diakses 20 Mei 2020.

${ }^{5}$ Gugus Tugas Percepatan Penangan Covid19, 20 Mei 2020.
}

langsung beban ekonomi masyarakat semakin tinggi karena tidak dapat beraktivitas secara normal. Oleh karena itu, dibutuhkan peran serta institusi politik lain, seperti partai politik untuk bahumembahu dengan pemerintah untuk mengurangi beban masyarakat.

Di Kecamatan Tompobulu, saat menjelang pemilihan umum, partai politik aktif memberikan bantuan dan sumbangan kepada masyarakat, namun di saat pandemi ini hanya beberapa partai politik yang terjun ke masyarakat memberikan bantuan seperti Alat Pelindung Diri (APD) di Puskesmas dan masjid, bantuan sembako kepada beberapa kepala rumah tangga yang berkategori tidak mampu.

Pada hal, situasi seperti ini adalah momen bagi partai politik untuk menunjukkan kepeduliannya kepada masyarakat yang juga menjadi bagian dari pemasaran politiknya. Philip Kotler dan Neil Kotler dalam "Political Marketing: Generating Effective. Candidates, Campaigns, and Causes" menjelaskan bagaimana partai politik dapat memanfaatkan strategi pemasaran atau marketing demi mendapatkan suara. Konsep political marketing dapat diterapkan aktor politik, termasuk partai politik dengan menilai aspirasi publik serta momen tertentu sebagai "permintaan pasar" yang harus terus dipenuhi untuk dapat menuai citra terbaik. $^{6}$

\footnotetext{
${ }^{6}$ PinterPolitik.Com, 20 Mei 2020.
} 
Di tengah situasi seperti ini masyarakat pasti selalu menunggu uluran tangan partai politik, menunggu bantuan yang biasa mereka rasakan. Apalagi bagi masyarakat yang melihat berita melalui media televisi dan online pasti ingin mendapatkan bantuan yang demikian, seperti wawancara berikut.

Wawancara dengan Bapak Yunus:

"Loe ji kucini injo partai politika berbagi sabun pencuci tangan, hand sanitizer, masker, sembako tapi masih berskala di Kota-kota ya ji na di ibukota Jakarta partai politik angnyumbang doek untuk APD siagang bage-bage sembako. Punna kinne Mae dikamponga tenapa ia kucini pembagian sembako battu di partai politika”. 7

Artinya: "Banyak saya lihat partai politik berbagi pencuci tangan, hand sanitizer masker, sembako, tapi hanya di kota dan di Ibu Kota Jakarta partai politik menyumbang dana untuk APD serta bagibagi sembako. Tapi di sini di kampung kami belum melihat pembagian sembako dari partai politik".

Sementara itu, hasil wawancara dengan Ibu Kasmawati:

"Seharusna injo partai politika punna kaminne keadaanga pacce pangguppanga mae bage sembako, masker mange ri masyarakaka, tena na ladi memilih pa isse

\footnotetext{
${ }^{7}$ Yunus, Petani Sarroangin, wawancara, 28 April 2020.
}

na battu mae ri masyarakat ka bage sambako kammayya golla, kaluru', tarigu, minnyak, baju, talakko, bahkang doe biasa nabage-bage. Seharusna anjo punna terpilihmi ngallei peran selama kejadian virus Corona ya." 8

Artinya: "Seharusnya partai politik saat begini keadaan sulit mendapatkan penghasilan, datang berbagi sembako, masker ke masyarakat. Bukannya saat pemilu lagi baru ke masyarakat berbagi sembako seperti gula, rokok, terigu, minyak, baju, jilbab, bahkan uang bisanya mereka bagi ke masyarakat. Seharusnya itu jika terpilih harus mengambil peran selama pandemi Covid-19 ini."

Di tengah masyarakat mengharapkan bantuan, Partai Gerakan Indonesia Raya (Gerindra) melalui akun media sosialnya ikut berkontribusi memberikan bantuan di Puskesmas Tompobulu berupa baju hazmat, masker, hand sanitizer, face shield dan sepatu boots yang diterima langsung oleh kepala Puskesmas Tompobulu. Selain itu, bantuan sembako juga diberikan kepada beberapa kepala rumah tangga kategori tidak mampu di sekitar daerah Puskesmas. ${ }^{9}$

Selain itu, Partai Keadilan Sejahtera (PKS) juga membagikan sabun pencuci tangan dan hand zanitiser ke setiap masjid di

\footnotetext{
${ }^{8}$ Kasmawati, Ibu Rumah Tangga Sarroangin, wawancara, 19 Apil 2020.

${ }^{9}$ Saenal Abidin, "Ketua Fraksi Gerindra Gowa Salurkan APD ke PKM Tompobulu" dalam https://faktual.net/ketua-fraksi-gerindra-gowa-sal urkan-apd-ke-pkm-tompobulu/, diakses 23 Mei 2020 .
} 
Tompobulu dan posko keamanan Pembatasan Sosial Berskala Besar (PSBB), seperti wawancara berikut.

Wawancara dengan Riskawati:

"Beberapa partai politik adami bantuannya masuk seperti di Puskesmas berupa APD, ada juga di masjid-masjid dibagikan saya lihat pencuci tangan dan hand zanitiser. Tapi kalo sembako tidak lihatpa ia, semoga kedepannya adami juga sembako diberikan kepada masyarakat yang kurang mampu." 10

Di tengah pandemic Covid-19 ekonomi melemah dan banyak masyarakat mulai kekurangan pendapatan mata pencaharian, karena mayoritas masyarakat Tompobulu adalah petani, maka otomatis hasil taninya juga akan berdampak pada hasil panennya seperti turunnya harga hasil pertanian dan mengalami kerugian karena biaya penanaman lebih banyak dibandingkan hasil yang didapat. Seperti wawancara berikut dengan aparat desa.

Wawancara dengan Ibu Nurwahidayanti:

Di tengah pandemi Covid-19 saya berharap partai politik berlomba-lomba dalam memberikan bantuan sembako kepada masyarakat, karena mengingat perekonomian di masyarakat saat ini sangat sulit banyak yang petani yang mengalami kerugian akibat pandemi dan peneran PSBB dan Lockdown sehingga

\footnotetext{
${ }^{10}$ Riskawati, Pegawai Puskesmas, wawancara, 23 Mei 2020.
}

harga sayur menjadi murah busuk dan tidak terjual yang biasa kita bisa jual ke Makassar kini terbatas. Saya melihat juga ada partai PKS provinsi membagikan sabun pencuci tangan dan hand sanitizer di tiap masjid di Tompobulu. Saya berharap semoga kedepannya ada partai politik yang berbagi sembako bagi warga kurang mampu. ${ }^{11}$

Banyak dampak yang ditimbulkan oleh pandemi ini, selain berdampak pada bidang pertanian juga berdampak pada ibu-ibu rumah tangga yang memiliki profesi penjual, baik di pasar maupun di rumah. Pendapatan semakin berkurang karena adanya aturan pemerintah untuk menerapkan Social Distancing dan PSBB.

Wawancara dengan Ibu Mira:

"Injo ibu2 ka na Boya kabiasanna angguppa sembako bahkan doek battu partai politika. Apalagi inne gitte kodong punna petani jaki na punna kaminne paccemi pangguppanga tena paballi ripasaraka. Berharap Anjo ibu-ibu ka angguppa sembako pembagian singkamma punna la pemilihangi towwa".

Artinya: "Itu ibu-ibu mencari kebiasaannya mendapat sembako bahkan uang dari partai politik. Apalagi kini ini hanya petani, jika keadaan susah begini pendapatan juga berkurang, karena kurang pembeli di pasar. Ibu-ibu berharap

\footnotetext{
${ }^{11}$ Nurwahidayanti, Aparat Desa, wawancara, 24 April 2020.
} 
mendapatkan pembagian sembako seperti kebiasaan di waktu sebelum pemilihan."

Dalam hal ini, setiap partai politik yang ada seharusnya dapat memanfaatkan kesempatan emas di saat masyarakat mengalami kesulitan akibat pandemi Covid-19 untuk membuktikan bahwa komitmen serta kepedulian mereka terhadap suara rakyat jelas dan nyata. Tentunya partai politik mana yang berhasil memanfaatkan momentum dengan memberikan bantuan secara terstruktur serta berkelanjutan di seluruh wilayah Indonesia tentu akan mendapatkan keuntungan strategis bagi citra dan kredibilitas partai politik tersebut. ${ }^{12}$

Wawancara dengan Bapak Sampara:

"Saya sebagai $R W$ selalu menunggu niat baik partai politik, ini adalah momentum paling baik untuk menarik perhatian dan mengambil hati masyarakat berbagi di tengah pandemi covid-19 ini. Semoga ada partai politik yang terketuk hatinya, meskipun Adami partai PKS membagikan pencuci tangan di masjid-masjid $k a$ sebuah langkah yang baik'. 13

Pandemi Covid-19 sepertinya mulai membuka mata dan hati masyarakat saat ini bahwa untuk bertahan dan bangkit dari situasi ini adalah dengan saling bahu membahu satu sama lain antar seluruh elemen masyarakat, tidak terkecuali partai politik. Partai politik harus pandai menarik

\footnotetext{
${ }^{12}$ Pinter Politik, 20 Mei 2020.

${ }^{13}$ Sampara, Ketua RW wawancara, 05 April 2020.
}

simpati serta menjawab kesan bahwa partai politik hanya hadir di saat pemilihan saja, namun dengan berupaya mengambil momentum ini untuk memberikan bantuan-bantuan sederhana.

\section{KESIMPULAN}

Penulis dapat menyimpulkan bahwa beberapa di antara partai politik turut serta membantu pemerintah dalam hal ini memberikan sumbangsih dan bantuan kepada masyarakat dalam bentuk Alat Pelindung Diri (APD), sabun pencuci tangan, hand zanitiser ke puskesmas, serta pembagian sembako beberapa kepala keluarga kurang mampu. Selain itu, masyarakat sangat memahami bahwa partai politik memiliki peranan penting menjadi garda terdepan bersama pemerintah melawan pandemi ini dan berharap agar partai politik dapat memberikan bantuan bukan hanya datang di waktu kampanye dengan bantuan masif.

$* * *$

\section{DAFTAR PUSTAKA}

Gugus Tugas Percepatan Penangan Covid19, "Data Sebaran" dalam covid19.co.id, diakses 20 Mei 2020.

Payerli Pasaribu, "Peranan Partai Politik dalam Melaksanakan Pendidikan Politik, JPPUMA: Jurnal Ilmu Pemerintahan dan Sosial Politik, 5 (1) (2017): 51-59.

PinterPolitik.Com, "PKS - Demokrat Bersinar di Tengah Corona" dalam 
https://www.pinterpolitik.com/pksdemokrat-bersinar-di-tengah-corona/, diakses 20 Mei 2020.

Saenal Abidin, "Ketua Fraksi Gerindra Gowa Salurkan APD ke PKM Tompobulu" dalam https://faktual.net/ ketua-fraksi-gerindr a-gowa-salurkanapd-ke-pkm-tompob ulu/, diakses 23 Mei 2020.

\section{Wawancara}

Kasmawati, Ibu Rumah Tangga Sarroangin, wawancara, 19 Apil 2020.

Nurwahidayanti, Aparat Desa, wawancara, 24 April 2020.

Riskawati, Pegawai Puskesmas, wawancara, 23 Mei 2020.

Sampara, Ketua RW Sarroangin, wawancara, 05 April 2020.

Yunus, Petani Sarroangin, wawancara, 28 April 2020. 